\title{
Comparing the Performance of Protected and Unprotected Areas in Conserving Freshwater Fish Abundance and Biodiversity in Lake Tanganyika, Tanzania
}

\author{
Emmanuel Andrew Sweke, ${ }^{1,2}$ Julius Michael Assam, ${ }^{1}$ Abdillahi Ismail Chande, ${ }^{1,3}$ \\ Athanasio Stephano Mbonde, ${ }^{1}$ Magnus Mosha, ${ }^{4}$ and Abel Mtui ${ }^{4,5}$ \\ ${ }^{1}$ Tanzania Fisheries Research Institute, P.O. Box 90, Kigoma, Tanzania \\ ${ }^{2}$ Graduate School of Fisheries Sciences, Hokkaido University, 3-1-1 Minato-cho, Hakodate 041-8611, Japan \\ ${ }^{3}$ College of Science, Informatics and Built Environment, Bagamoyo University, P.O. Box 75254, Dar es Salaam, Tanzania \\ ${ }^{4}$ Mahale Mountains National Park, P.O. Box 1374, Kigoma, Tanzania \\ ${ }^{5}$ Tanzania National Parks, P.O. Box 3134, Arusha, Tanzania
}

Correspondence should be addressed to Emmanuel Andrew Sweke; esweke@yahoo.com

Received 18 February 2016; Accepted 12 June 2016

Academic Editor: Michel Couderchet

Copyright (C) 2016 Emmanuel Andrew Sweke et al. This is an open access article distributed under the Creative Commons Attribution License, which permits unrestricted use, distribution, and reproduction in any medium, provided the original work is properly cited.

\begin{abstract}
Marine protected areas have been shown to conserve aquatic resources including fish, but few studies have been conducted of protected areas in freshwater environments. This is particularly true of Lake Tanganyika, Tanzania. To better conserve the lake's biodiversity, an understanding of the role played by protected areas in conserving fish abundance and diversity is needed. Sampling of fish and environmental parameters was performed within the Mahale Mountains National Park (MMNP) and nearby unprotected areas at depths between $5 \mathrm{~m}$ and $10 \mathrm{~m}$. Twelve replicates of fish sampling were performed at each site using gillnets set perpendicularly to the shore. Mann-Whitney tests were performed, and the total amount of species turnover was calculated. A total of 518 individual fish from 57 species were recorded in the survey. The fish weight abundance was fivefold greater in the MMNP than in the unprotected areas. Fish abundance and diversity were higher in the MMNP than in the unprotected areas and decreased with distance from it. Our findings confirmed the importance of the protected area in conserving fish resources in Lake Tanganyika. The study provides baseline information for management of the resources and guiding future studies in the lake and other related ecosystems. Management approaches that foster awareness and engage with communities surrounding the MMNP are recommended for successful conservation of the resources in the region.
\end{abstract}

\section{Introduction}

The complexity of the Lake Tanganyika (Figure 1) ecosystem makes it unique in the world [1], and it notably contributes to global biodiversity $[2,3]$. About $58 \%$ of the animal species that inhabit the lake are endemic [4], and fish of the family Cichlidae and Molluscs are very diverse; that is, both of these groups have a high number of species with a substantial proportion of endemic species [5] and show considerable genetic variability within species. However, the lake's biodiversity is vulnerable to anthropogenic threats including fishing [5-10].
Conservation researchers have advocated controlling human activities by establishing protected areas as one of the methods of conserving biodiversity in an ecosystem $[9,11$, 12]. This mitigation approach ensures that some essentially unmodified sites exist for buffering against uncertainty such as overfishing $[13,14]$. It is well documented that protected areas nurse and harbor many more species compared with unprotected areas $[11,12,15]$. Additionally, studies of freshwater ecosystems have revealed that fish in protected areas are larger than those in unprotected areas [16-18]. Unfortunately, many protected areas are designed to conserve terrestrial 

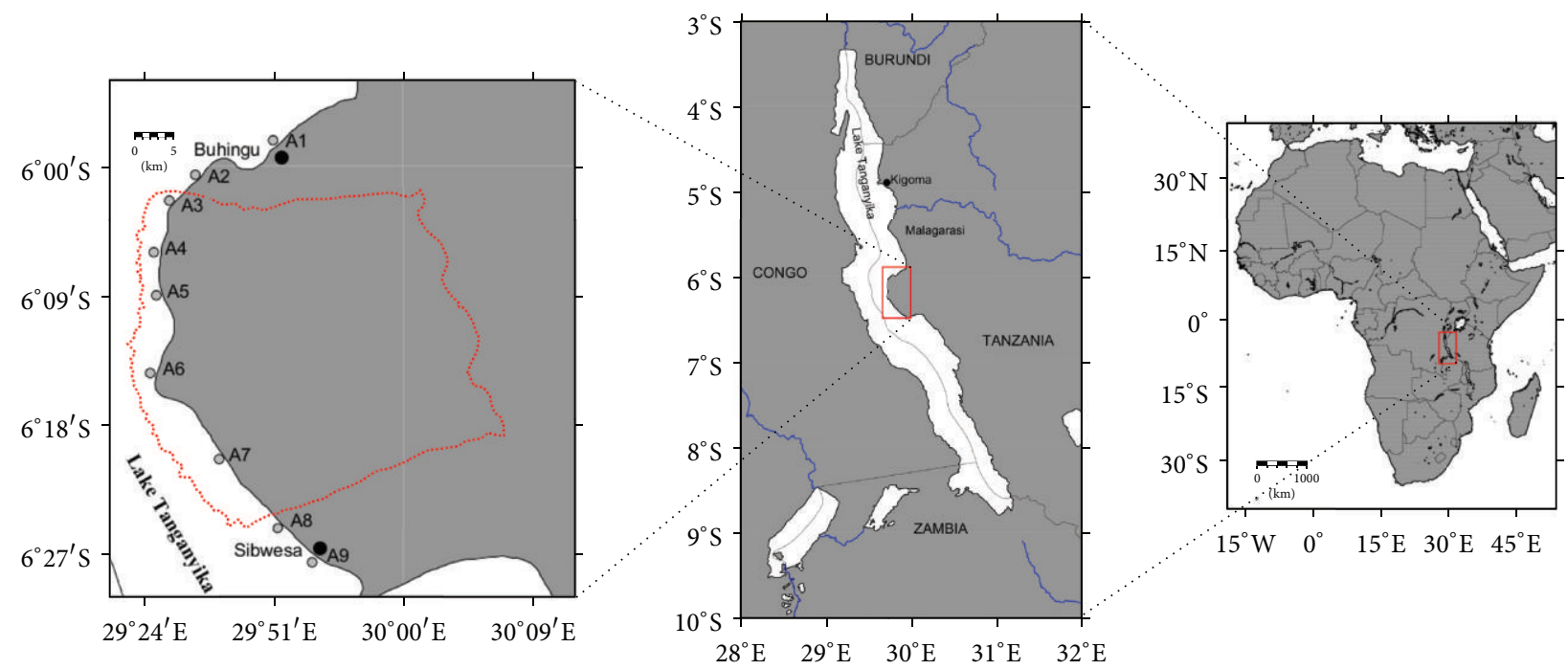

FIGURE 1: Map of Lake Tanganyika showing study sites within protected area (MMNP: A3-A7) and in unprotected areas (Buhingu: A1-A2 and Sibwesa: A8-A9) during 2008 gillnet survey. The large red polygon in the first frame shows sketch boundaries of MMNP (terrestrial and water strip in grey color and white color, resp.). The blue lines in the middle frame represent rivers.

habitats than aquatic biodiversity, consequently limiting the assessment of spatial and temporal fish abundance and biodiversity in both protected and unprotected areas [19-22].

The Mahale Mountains National Park (MMNP) was established in 1985 to conserve terrestrial biodiversity, with a particular aim of protecting chimpanzees. The MMNP has a total area of $1,613 \mathrm{~km}^{2}$, of which $96 \mathrm{~km}^{2}$ is a $1.6 \mathrm{~km}$ wide aquatic strip extending along the shore of Lake Tanganyika [23]. All forms of exploitation including fishing are strictly prohibited in the MMNP. Trained park rangers conduct patrols to prevent poaching. However, fishing activities in surrounding waters remain unregulated. The ecological performance of protected areas has been assessed by comparing it with that of nearby unprotected areas [24, 25]. However, studies on the MMNP's biological conservation efficacy and loss of fish abundance and diversity in adjacent areas are scarce.

The purpose of this study was to assess and compare the differences in fisheries resources between protected and unprotected areas. To achieve this, we compared fish abundance and diversity between the MMNP and nearby unprotected areas. Such studies are vitally important to ascertain the spatial and temporal extent of human influence in variations in abundance and diversity in the ecosystem. This baseline information also could contribute valuable knowledge to the global debate concerning the relevance of freshwater protected areas in conserving fisheries resources.

\section{Methods}

2.1. Study Area Description. The study was conducted in Lake Tanganyika, Tanzania, during May and June 2008. Sampling sites were located within and outside the MMNP (Figure 1). The MMNP is located at the southern edge of the Kigoma region, with an elevation ranging from 2,000 to 2,400 $\mathrm{m}$ [26].
2.2. Data Collection. For comparison purposes, the sampling sites were selected based on area status, that is, protected and unprotected, Table 1. Eight sampling sites (four within the protected area (MMNP) and four in unprotected areas) at least $5 \mathrm{~km}$ apart were randomly selected. The four outermost sites (i.e., two northernmost and two southernmost) were located in unprotected areas (Buhingu and Sibwesa villages, resp.).

2.3. Environmental Parameters. Four samples for dissolved oxygen (DO) and temperature were taken at each site at $5 \mathrm{~m}$ and $10 \mathrm{~m}$ water depths using a multiparameter analyzer WTW 340i [27]. The mean values of environmental parameters were statistically analyzed using a one-way ANOVA.

2.4. Sampling of Fish. The sampling of fish was performed at depths between $5 \mathrm{~m}$ and $10 \mathrm{~m}$ using gillnet set perpendicularly to the shore. Twelve replicates of gillnets, each with a width of $1.37 \mathrm{~m}$ and $45 \mathrm{~m}$ total length (before mounting), were joined end to end to form one panel of $360 \mathrm{~m}$. The mesh sizes ranged from $1^{\prime \prime}$ to $5^{\prime \prime}$ (inches) (i.e., $25.4 \mathrm{~mm}$ to $127.0 \mathrm{~mm}$ ), at an interval of $0.5^{\prime \prime}$ except for the large mesh sizes (i.e., $1^{\prime \prime}$, $1.5^{\prime \prime}, 2^{\prime \prime}, 2.5^{\prime \prime}, 3^{\prime \prime}, 3.5^{\prime \prime}, 4^{\prime \prime}$, and $\left.5^{\prime \prime}\right)$. The first 4 mesh size nets $\left(1^{\prime \prime}\right.$ to $\left.2.5^{\prime \prime}\right)$ were used in pairs. Each net had a length of $30 \mathrm{~m}$ after mounting at a hanging ratio of 0.66 . Nets of different mesh sizes were used to increase the variability of sizes of fish and minimize sampling errors. The nets were set in the evening and hauled in the following morning. After hauling, the samples were sorted and identified to species level at the shore according to Konings [28]. Total catch, species, and wet weights of fish were recorded at each site. After the experiments, some of the fish samples were used for human consumption and representatives of some species were preserved for reference. 
TABLE 1: Environmental parameters mean $( \pm S D)$ of study sites in protected and unprotected areas in Lake Tanganyika, Tanzania, from gillnet survey during 2008. Samples from site A4 were omitted in the analysis.

\begin{tabular}{lcccc}
\hline Site ID & Site location & Status & DO $\left(\mathrm{mg} \cdot \mathrm{L}^{-1}\right)$ & Temperature $\left({ }^{\circ} \mathrm{C}\right)$ \\
\hline A1 & Buhingu & Unprotected & $8.45 \pm 0.21$ & $26.95 \pm 0.07$ \\
A2 & Buhingu & Unprotected & $7.30 \pm 0.14$ & $26.95 \pm 0.07$ \\
A3 & MMNP & Protected & $8.00 \pm 0.14$ & $27.05 \pm 0.07$ \\
A4 & MMNP & Protected & $7.70 \pm 0.42$ & $27.50 \pm 0.00$ \\
A5 & MMNP & Protected & $7.35 \pm 0.35$ & $27.05 \pm 0.07$ \\
A6 & MMNP & Protected & $7.25 \pm 0.21$ & $27.20 \pm 0.00$ \\
A7 & MMNP & Protected & $8.15 \pm 0.07$ & $26.65 \pm 0.07$ \\
A8 & Sibwesa & Unprotected & $7.25 \pm 0.21$ & $26.00 \pm 0.00$ \\
A9 & Sibwesa & Unprotected & $7.50 \pm 0.28$ & $26.30 \pm 0.00$ \\
\hline
\end{tabular}

2.5. Estimation of Abundance of Fish Species. To select appropriate statistical tests, fish mean abundance data and their residuals were tested for normality. The data were not normally distributed and variance groups were heterogeneous. This was followed by a log transformation, but the data still did not assume normal distribution patterns. Owing to this, we performed nonparametric tests after Mann-Whitney (MW) tests to determine pairs of areas with significant differences in fish abundance. The latter test was also performed to determine if habitat types affected fish abundance in the unprotected areas. Additionally, to avoid bias in the analysis, data from the rocky habitat in the MMNP was omitted; that is, data from 8 sites was used: four from within the MMNP and the 4 from the adjacent unprotected areas.

2.6. Calculation of Diversity of Fish Species. Fish biodiversity in both protected and unprotected areas was calculated as absolute species turnover, that is, the total amount of species turnover among the subunits in the dataset [29]:

$$
\beta_{\mathrm{A}}=\left(S_{1}-c\right)+\left(S_{2}-c\right)+\cdots+\left(S_{n}-c\right),
$$

where $\beta_{\mathrm{A}}$ is the absolute species turnover (diversity) for area A, $S_{1}$ is the total number of species recorded in the first site, $S_{2}$ is the total number of species recorded in the second site, $S_{n}$ is the total number of species recorded in the $n$th site, and $c$ is the number of species common to both sites.

Statistical tests for the environmental parameters and fish abundance were performed at significance level, $P=0.05$, using STATISTICA (version 8, StatSoft Inc., 2010).

\section{Results}

3.1. Environmental Parameters. There were no significant differences in dissolved oxygen $\left(F_{1,16}=0.73, P=0.41\right)$ and temperature $\left(F_{1,16}=2.60 \times 10^{-3}, P=0.96\right)$ between the protected and unprotected areas (Table 1).

3.2. Abundance (Number) of Individual Fish. The mean number of individuals of fish in sites within the MMNP was higher than in the unprotected areas (Mann-Whitney, $P<0.05$ ). In the survey, 518 individual fish from 57 species were recorded: 40 species were recorded in the MMNP and 39 were recorded

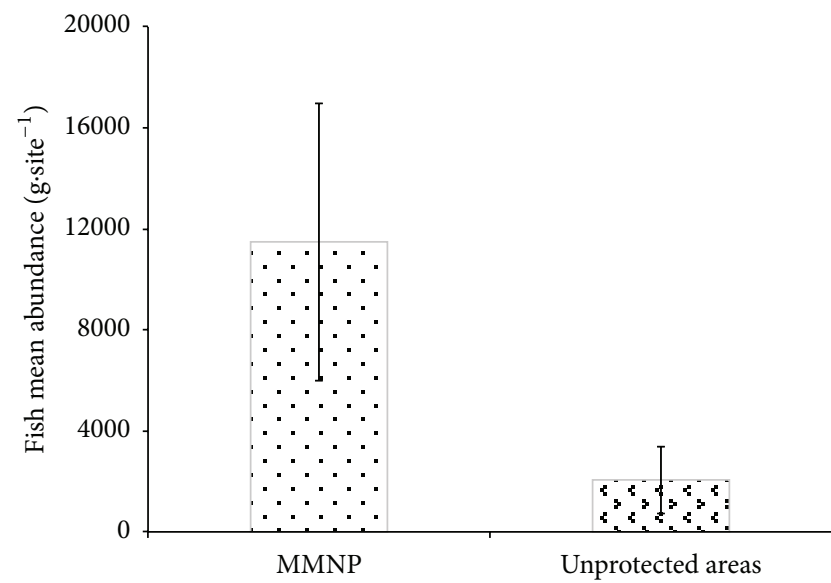

FIGURE 2: Mean fish abundance (wet weight \pm SD) within protected area (MMNP) and unprotected areas (Buhingu and Sibwesa) in Lake Tanganyika, Tanzania, during 2008 gillnet survey.

in the unprotected areas (Table 2). The species belonged to nine families (number of species in parentheses): Cichlidae (41), Mastacembelidae (3), Mochokidae (3), Claroteidae (3), Latidae (2), Mormyridae (2), Clupeidae (1), Cyprinidae (1), and Poeciliidae (1). Haplotaxodon microlepis and Bathybagrus graueri were the most abundant species recorded in both the protected and unprotected areas (Table 2). The former ranked the first in abundance in both the MMNP and unprotected areas, and the latter was the sixth and fourth in the MMNP and unprotected areas, respectively. Five of the 10 most abundant species in the MMNP area were not recorded in the unprotected areas. On the other hand, only two species (Synodontis spp. and Bathybates graueri) which were among the most abundant ones in the unprotected areas were not recorded in the MMNP area. The two unprotected areas (Buhingu and Sibwesa) showed significant difference in the mean fish abundance (Mann-Whitney, $P<0.05$ ). However, mean fish abundance was not significantly different between habitat types, particularly rocky and sandy types in the unprotected areas (Mann-Whitney, $P=0.16$ ).

3.3. Weight Abundance. Figure 2 shows the mean wet weight of the fish samples in both the MMNP and the unprotected 
TABLE 2: Mean abundance number of individuals $( \pm$ SE) of fish species sampled in sites within the protected area $(\mathrm{MMNP})$ and unprotected areas (Buhingu and Sibwesa) in Lake Tanganyika, Tanzania, during 2008 gillnet survey.

\begin{tabular}{|c|c|c|}
\hline Fish species & Protected area & Unprotected areas \\
\hline Haplotaxodon microlepis & $9.00 \pm 4.60$ & $5.75 \pm 4.42$ \\
\hline Limnotilapia dardennii & $7.75 \pm 2.50$ & $0.75 \pm 0.48$ \\
\hline Barbus sp. & $7.75 \pm 2.17$ & 0 \\
\hline Lates angustifrons & $6.50 \pm 1.66$ & 0 \\
\hline Bathybates hornii & $6.00 \pm 2.48$ & $0.25 \pm 0.25$ \\
\hline Limnothrissa miodon & $5.50 \pm 4.52$ & 0 \\
\hline Bathybagrus graueri & $5.00 \pm 1.78$ & $3.00 \pm 2.68$ \\
\hline Lamprichthys tanganicanus & $4.25 \pm 1.93$ & 0 \\
\hline Petrochromis moshi & $3.50 \pm 3.50$ & $1.25 \pm 1.25$ \\
\hline Boulengerochromis microlepis & $3.50 \pm 0.87$ & $0.25 \pm 0.25$ \\
\hline Lepidiolamprologus elongatus & $3.25 \pm 2.63$ & 0 \\
\hline Plecodus paradoxus & $3.00 \pm 0.82$ & $1.00 \pm 0.71$ \\
\hline Cyathopharynx foai & $2.75 \pm 1.80$ & $0.50 \pm 0.29$ \\
\hline Lamprologus callipterus & $2.00 \pm 0.82$ & $0.25 \pm 0.25$ \\
\hline Grammatotria lemairii & $1.50 \pm 1.19$ & $0.25 \pm 0.25$ \\
\hline Petrochromis orthognathus & $1.50 \pm 0.96$ & 0 \\
\hline Lepidiolamprologus cunningtoni & $1.50 \pm 0.87$ & 0 \\
\hline Ophthalmotilapia nasuta & $1.25 \pm 1.25$ & $1.75 \pm 1.44$ \\
\hline Synodontis petricola & $1.25 \pm 0.95$ & $0.25 \pm 0.25$ \\
\hline Tropheus moorii & $1.00 \pm 1.00$ & 0 \\
\hline Cyphotilapia frontosa & $0.75 \pm 0.75$ & $0.50 \pm 0.50$ \\
\hline Lates mariae & $0.75 \pm 0.75$ & $0.25 \pm 0.25$ \\
\hline Aulonocranus dewindti & $0.75 \pm 0.48$ & $2.00 \pm 2.00$ \\
\hline Plecodus straeleni & $0.75 \pm 0.48$ & $1.25 \pm 0.95$ \\
\hline Neolamprologus mustax & $0.75 \pm 0.48$ & $0.50 \pm 0.50$ \\
\hline Tylochromis polylepis & $0.75 \pm 0.48$ & $0.50 \pm 0.50$ \\
\hline Neolamprologus fasciatus & $0.75 \pm 0.48$ & $0.50 \pm 0.50$ \\
\hline Perissodus microlepis & $0.75 \pm 0.48$ & 0 \\
\hline Lepidiolamprologus profundicola & $0.75 \pm 0.48$ & 0 \\
\hline Xenotilapia melanogenys & $0.50 \pm 0.50$ & 0 \\
\hline Lobochilotes labiatus & $0.50 \pm 0.29$ & 0 \\
\hline Xenotilapia sima & $0.25 \pm 0.25$ & $1.25 \pm 1.25$ \\
\hline Lamprologus lemairii & $0.25 \pm 0.25$ & $0.75 \pm 0.75$ \\
\hline Xenotilapia spiloptera & $0.25 \pm 0.25$ & $0.25 \pm 0.25$ \\
\hline Petrochromis famula & $0.25 \pm 0.25$ & 0 \\
\hline Bathybates ferox & $0.25 \pm 0.25$ & 0 \\
\hline Mastacembelus cunningtoni & $0.25 \pm 0.25$ & 0 \\
\hline Auchenoglanis occidentalis & $0.25 \pm 0.25$ & 0 \\
\hline Tropheus annectens & $0.25 \pm 0.25$ & 0 \\
\hline Simochromis diagramma & $0.25 \pm 0.25$ & 0 \\
\hline Synodontis sp. & 0 & $5.25 \pm 4.61$ \\
\hline Bathybates graueri & 0 & $3.25 \pm 3.25$ \\
\hline Phyllonemus typus & 0 & $2.00 \pm 2.00$ \\
\hline Ectodus descampsii & 0 & $1.50 \pm 1.50$ \\
\hline Petrochromis fasciolatus & 0 & $1.25 \pm 1.25$ \\
\hline Mastacembelus sp. & 0 & $1.00 \pm 1.00$ \\
\hline Neolamprologus toae & 0 & $1.00 \pm 0.41$ \\
\hline Telmatochromis brichardi & 0 & $0.75 \pm 0.75$ \\
\hline Benthochromis tricoti & 0 & $0.75 \pm 0.75$ \\
\hline Mormyrus sp. & 0 & $0.25 \pm 0.25$ \\
\hline Mastacembelus moorii & 0 & $0.25 \pm 0.25$ \\
\hline
\end{tabular}


TABLE 2: Continued.

\begin{tabular}{lcc}
\hline Fish species & Protected area & Unprotected areas \\
\hline Synodontis multipunctatus & 0 & $0.25 \pm 0.25$ \\
Hippopotamyrus sp. & 0 & $0.25 \pm 0.25$ \\
Altolamprologus compressiceps & 0 & $0.25 \pm 0.25$ \\
Petrochromis ephippium & 0 & $0.25 \pm 0.25$ \\
Lepidiolamprologus attenuatus & 0 & $0.25 \pm 0.25$ \\
Neolamprologus pleuromaculatus & 0 & $0.25 \pm 0.25$ \\
Total number of individual fish & 351 & 167 \\
Average number of individual fish per site & $87.75 \pm 46.16$ & $41.75 \pm 37.47$ \\
\hline
\end{tabular}

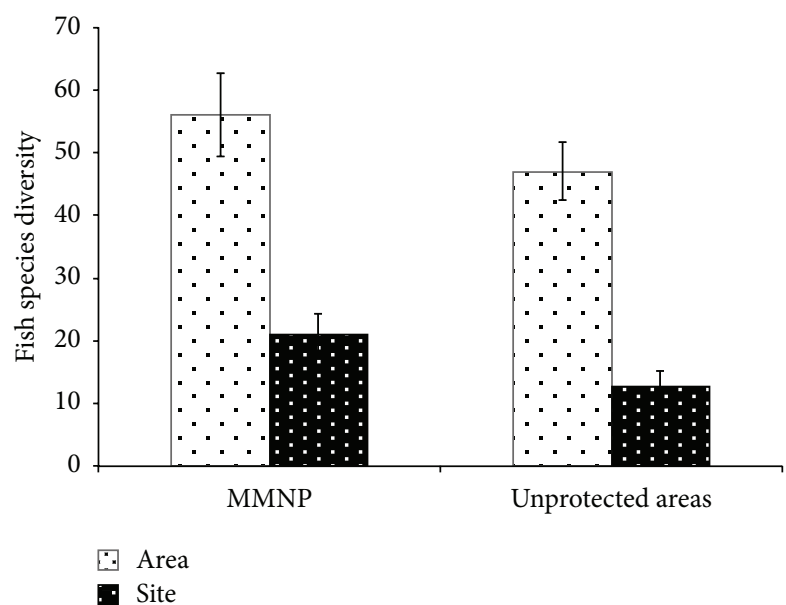

Figure 3: Mean fish species diversity $( \pm S D)$ calculated as absolute species turnover in protected area (MMNP) and unprotected areas (Buhingu and Sibwesa) in Lake Tanganyika, Tanzania, during 2008 gillnet survey.

areas. There was a significant difference (Mann-Whitney, $P<0.05)$ in weight abundance between the MMNP and the unprotected areas. The abundance in the MMNP was fivefold greater than in the unprotected area. The highest weight $\left(19,300 \mathrm{~g} \cdot \mathrm{site}^{-1}\right)$ was recorded in the MMNP, whereas the lowest $\left(844 \mathrm{~g} \cdot \mathrm{site}^{-1}\right.$ ) was recorded in unprotected areas (Buhingu).

3.4. Fish Species Diversity. The mean species diversity turnover was higher in the MMNP than in the unprotected areas (Figure 3). The number of species within the MMNP's sites was almost double that of the unprotected areas. The sites with the highest and lowest species diversity were recorded in the MMNP $(n=30)$ and unprotected areas $(n=8)$, respectively. The fish diversity decreased with distance from the MMNP where 23 and 16 species were recorded in Buhingu and Sibwesa, respectively.

\section{Discussion}

The main findings of this study are that there are higher fish species diversity and abundance of fish in the MMNP compared with the unprotected areas. We discuss these findings in the subsequent text, to illustrate the performance differences between the MMNP and the unprotected areas in conserving fish abundance and biodiversity in the lake.

4.1. Environmental Parameters. Insignificant differences in the environmental parameters between protected and unprotected areas ruled out their effects on fish species diversity and abundance in the areas. Upwelling driven by strong southeast winds that prevail during the sampling period (dry season, i.e., May-September) $[30,31]$ might have attributed to the similarity in the parameters.

4.2. Abundance (Number) of Individual Fish. The dominance of different fish species within the MMNP suggests that the area is richer in fish species than the adjacent unprotected areas. Fish species in the families Clupeidae, Cyprinidae, and Poeciliidae were recorded only in MMNP and were among the most abundant species. Conversely, sites in the unprotected areas were characterized by few species that notably contributed to the abundance in these areas. This was exemplified by the two most dominant species Haplotaxodon microlepis and Aulonocranus dewindti that (out of 17 species in the area) constituted about $50 \%$ of fish counts in Sibwesa.

4.3. Weight Abundance. The current findings affirm the assumed abundance of socially and economically important fish species such as Lates angustifrons, Boulengerochromis microlepis, and Limnotilapia dardennii in the protected area. There was higher mean abundance within the protected area than in adjacent unprotected areas (Figure 2), which suggests that the MMNP harbors larger individual fish compared to the unprotected areas. In other words, individuals of exploited species were relatively larger in protected areas than in open-access areas. Fish size is used as an indicator of fishing pressure; fish are likely to be smaller in areas that are more heavily fished $[12,15,32]$. These are some positive indications of the effectiveness of the MMNP in conserving fish abundance and diversity in the lake.

4.4. Fish Species Diversity. The differences in fish diversity between the MMNP and unprotected areas (Figure 3) were probably due to differences in management of the resources. Whereas all forms of exploitation including fishing are strictly prohibited in the MMNP, fishing activities in surrounding waters are high $[8,10]$. Poor enforcement of existing fisheries regulations by the local and regional authorities may also 
be attributed to low fish diversity in the unprotected areas. For instance, the use of prohibited beach seine nets was confirmed at Sibwesa during the survey. This could be one of the reasons why the sites in this area recorded the lowest fish species diversity. Identification of any signal of change in the ecosystem that will lead to taking immediate management and conservation measures is especially important [33].

\section{Conclusions}

Comparisons of fish abundance, especially of fish weight, and diversity showed that the MMNP plays an important role in conserving fisheries resources in the region. Extending the park or establishing more other protected areas could certainly enhance biodiversity in the region. However, this should be carefully considered because it might redirect fishing pressure to unprotected areas and cause more management challenges [34]. We believe that resources conservation approaches such as protected areas in the region cannot be successful through stringent laws and regulations but by creating awareness of the importance of protected areas among stakeholders. We advocate for socioecological studies, particularly on how communities surrounding the protected area should be engaged in enhancing sustainable fisheries resources management and conservation in the region.

Limitations of this study include inadequate sampling in rocky habitats in the MMNP, particularly in river mouths because they harbor dangerous animals such as Nile monitors, crocodiles, and hippopotamuses. Owing to this, we could not compare the influence of habitat types on fish abundance and diversity in the areas. Additionally, we could not find information on fish abundance and biodiversity before and after the addition of the water strip to the protected area. This precludes the comparison in a spatial and temporal basis of the variables in the areas. A similar paradox has been reported in other studies in freshwater protected areas [19-22]. Importantly, therefore, our work provides baseline information for the management of fisheries resources in Lake Tanganyika and guides future studies in the area.

\section{Ethical Approval}

The authors declare that the study was carried out in accordance with research ethical guidelines of the institutions and animal welfare including using environmentally friendly methods (i.e., gillnets).

\section{Competing Interests}

The authors declare that there are no competing interests regarding the publication of this paper.

\section{Acknowledgments}

This study was funded by the Tanzania National Parks (TANAPA), European Union (EU), and Frankfurt Zoological Society (FZS). The authors thank the Mahale Mountains National Park staff for logistics and support during sampling.
They are grateful to Robert Wakafumbe, George Kazumbe, Chande Rashid, and Jumanne Nuhu for their tireless efforts during data collection. They also thank Christopher Mulanda Aura, John Richard Bower, Adam Smith, Ismael Aaron Kimirei, and Samwel Mchele Limbu for their useful comments on the drafts of this paper.

\section{References}

[1] G. Hanek, E. J. Coenen, and P. Kotilainen, "Aerial frame survey of lake Tanganyika fisheries," FAO/ FINNIDA Research for the Management of the Fisheries on Lake Tanganyika, 1993.

[2] L. C. Beadle, The Inland Waters of Tropical Africa: An Introduction to Tropical Limnology, Longman, London, UK, 1974.

[3] A. S. Cohen, L. Kaufman, and R. Ogutu-Ohwayo, "Anthropogenic threats, impacts and conservation strategies in the African Great Lakes-a review," in Paleoclimatology East African Lakes, T. C. Johnson and E. O. Odada, Eds., The Limnology, Climatology and Paleoclimatology of the East African Lakes Gordon and Breach, pp. 575-624, Amsterdam, The Netherlands, 1996.

[4] G. W. Coulter, "Lake Tanganyika," in Speciation in Ancient Lakes, K. Martens, B. Goddeeris, and G. Coulter, Eds., Advances in Limnology, pp. 13-18, Schweizerbart Science, 1994.

[5] H. Mölsä, J. E. Reynolds, E. J. Coenen, and O. V. Lindqvist, "Fisheries research towards resource management on Lake Tanganyika," Hydrobiologia, vol. 407, pp. 1-24, 1999.

[6] E. J. Coenen, "Catch per unit effort (CPUE) study for different areas and fishing gears of Lake Tanganyika," FAO/FINNIDA Research for the Management of the Fisheries of Lake Tanganyika, 1995.

[7] G. Patterson and J. Makin, The State of Biodiversity in Lake Tanganyika: A Literature Review, Natural Resources Institute, Chatham, UK, 1998.

[8] I. A. Kimirei, Y. D. Mgaya, and A. I. Chande, "Changes in species composition and abundance of commercially important pelagic fish species in Kigoma area, Lake Tanganyika, Tanzania," Aquatic Ecosystem Health and Management, vol. 11, no. 1, pp. 29$35,2008$.

[9] C. Sturmbauer, "The Great Lakes in East Africa: biological conservation considerations for species flocks," Hydrobiologia, vol. 615, no. 1, pp. 95-101, 2008.

[10] M. Van der Knaap, "Comparative analysis of fisheries restoration and public participation in Lake Victoria and Lake Tanganyika," Aquatic Ecosystem Health and Management, vol. 16, no. 3, pp. 279-287, 2013.

[11] D. Pauly, V. Christensen, S. Guénette et al., "Towards sustainability in world fisheries," Nature, vol. 418, no. 6898, pp. 689695, 2002.

[12] F. Vandeperre, R. M. Higgins, J. Sánchez-Meca et al., "Effects of no-take area size and age of marine protected areas on fisheries yields: a meta-analytical approach," Fish and Fisheries, vol. 12, no. 4, pp. 412-426, 2011.

[13] G. W. Allison, S. D. Gaines, J. Lubchenco, and H. P. Possingham, "Ensuring persistence of marine reserves: catastrophes require adopting an insurance factor," Ecological Applications, vol. 13, no. 1, pp. S8-S24, 2003.

[14] F. R. Gell and C. M. Roberts, "Benefits beyond boundaries: the fishery effects of marine reserves," Trends in Ecology and Evolution, vol. 18, no. 9, pp. 448-455, 2003. 
[15] R. Sahyoun, S. Bussotti, A. Di Franco, A. Navone, P. Panzalis, and P. Guidetti, "Protection effects on Mediterranean fish assemblages associated with different rocky habitats," Journal of the Marine Biological Association of the United Kingdom, vol. 93, no. 2, pp. 425-435, 2013.

[16] R. A. Sanyanga, C. Machena, and N. Kautsky, "Abundance and distribution of inshore fish in fished and protected areas in Lake Kariba, Zimbabwe," Hydrobiologia, vol. 306, no. 1, pp. 67-78, 1995.

[17] L. Mancini, P. Formichetti, A. Anselmo, L. Tancioni, S. Marchini, and A. Sorace, "Biological quality of running waters in protected areas: the influence of size and land use," Biodiversity and Conservation, vol. 14, no. 2, pp. 351-364, 2005.

[18] J. Cucherousset, J.-M. Paillisson, A. Carpentier et al., "Freshwater protected areas: an effective measure to reconcile conservation and exploitation of the threatened European eels (Anguilla anguilla)?" Ecology of Freshwater Fish, vol. 16, no. 4, pp. 528-538, 2007.

[19] R. L. Pressey, G. L. Whish, T. W. Barrett, and M. E. Watts, "Effectiveness of protected areas in north-eastern New South Wales: recent trends in six measures," Biological Conservation, vol. 106, no. 1, pp. 57-69, 2002.

[20] R. Abell, S. Blanch, C. Revenga, and M. Thieme, "Conservation of aquatic ecosystems," in Encyclopedia of Inland Waters, G. E. Likens, Ed., pp. 249-258, Elsevier, Oxford, UK, 2009.

[21] D. Rodríguez-Olarte, D. C. Taphorn, and J. Lobón-Cerviá, "Do protected areas conserve neotropical freshwater fishes? A case study of a biogeographic province in Venezuela," Animal Biodiversity and Conservation, vol. 34, no. 2, pp. 273-285, 2011.

[22] J. M. Scott, F. W. Davis, R. G. McGhie, R. G. Wright, C. Groves, and J. Estes, "Nature reserves: do they capture the full range of America's biological diversity?” Ecological Applications, vol. 11, no. 4, pp. 999-1007, 2001.

[23] T. Nishida, The Chimpanzees of the Mahale Mountains: Sexual and Life History Strategies, University of Tokyo Press, Tokyo, Japan, 1980.

[24] J.-F. Mas, "Assessing protected area effectiveness using surrounding (buffer) areas environmentally similar to the target area," Environmental Monitoring and Assessment, vol. 105, no. 1-3, pp. 69-80, 2005.

[25] B. C. Chessman, "Do protected areas benefit freshwater species? A broad-scale assessment for fish in Australia’s Murray-Darling Basin," Journal of Applied Ecology, vol. 50, no. 4, pp. 969-976, 2013.

[26] JICA, Mahale: Study for the Proposed Mahale Mountains National Park, Japan International Cooperation Agency, 1980.

[27] R. G. Wetzel and G. E. Likens, Limnological Analyses, Springer, New York, NY, USA, 2000.

[28] A. Konings, Tanganyika Cichlids in Their Native Habitat, Cichlid Press, Lauenau, Germany, 1998.

[29] J. S. Albert and E. R. Roberto, Historical Biogeography of Neotropical Freshwater Fishes, University of California Press, Berkeley, Calif, USA, 2011.

[30] P.-D. Plisnier, D. Chitamwebwa, L. Mwape, K. Tshibangu, V. Langenberg, and E. Coenen, "Limnological annual cycle inferred from physical-chemical fluctuations at three stations of Lake Tanganyika," Hydrobiologia, vol. 407, pp. 45-58, 1999.

[31] J. R. Corman, P. B. McIntyre, B. Kuboja et al., "Upwelling couples chemical and biological dynamics across the littoral and pelagic zones of Lake Tanganyika, East Africa," Limnology and Oceanography, vol. 55, no. 1, pp. 214-224, 2010.
[32] S. E. Lester, B. S. Halpern, K. Grorud-Colvert et al., "Biological effects within no-take marine reserves: a global synthesis," Marine Ecology Progress Series, vol. 384, pp. 33-46, 2009.

[33] S. A. Black, "System behaviour charts inform an understanding of biodiversity recovery," International Journal of Ecology, vol. 2015, Article ID 787925, 6 pages, 2015.

[34] J. K. Abbott and A. C. Haynie, "What are we protecting? Fisher behavior and the unintended consequences of spatial closures as a fishery management tool," Ecological Applications, vol. 22, no. 3, pp. 762-777, 2012. 

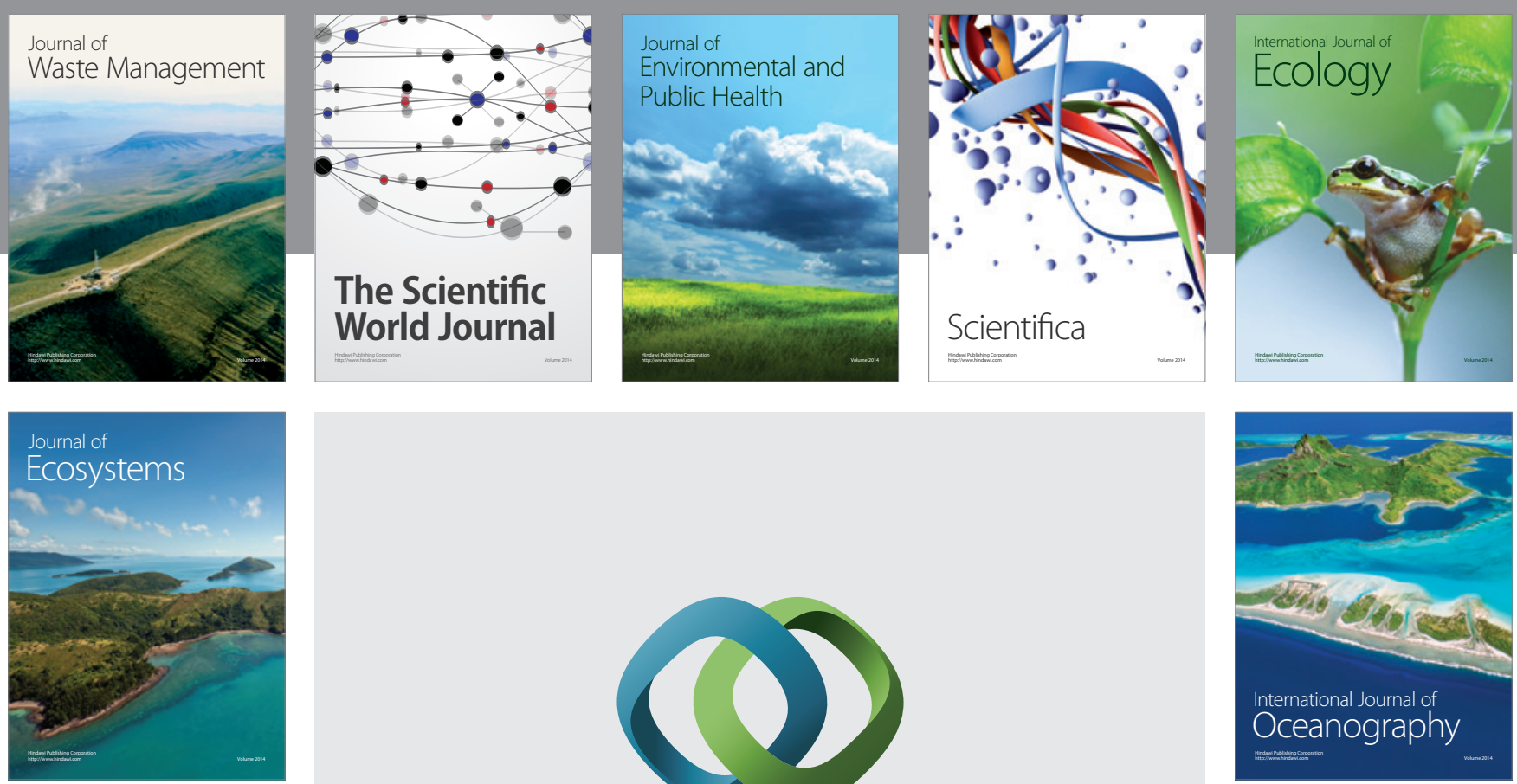

The Scientific World Journal
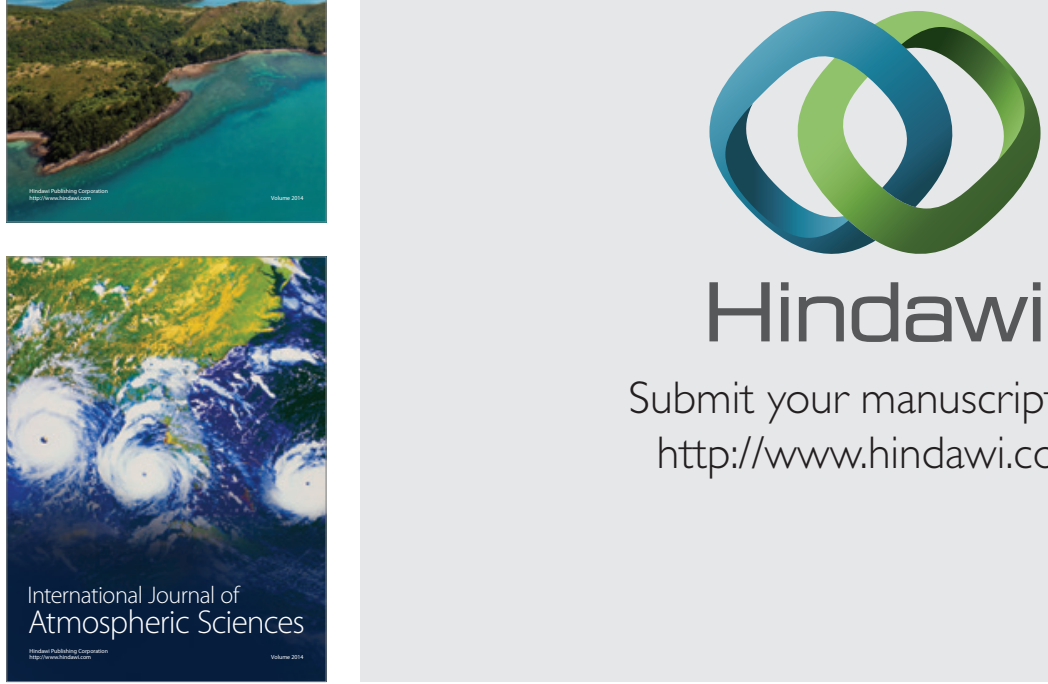

\section{Hindawi}

Submit your manuscripts at

http://www.hindawi.com
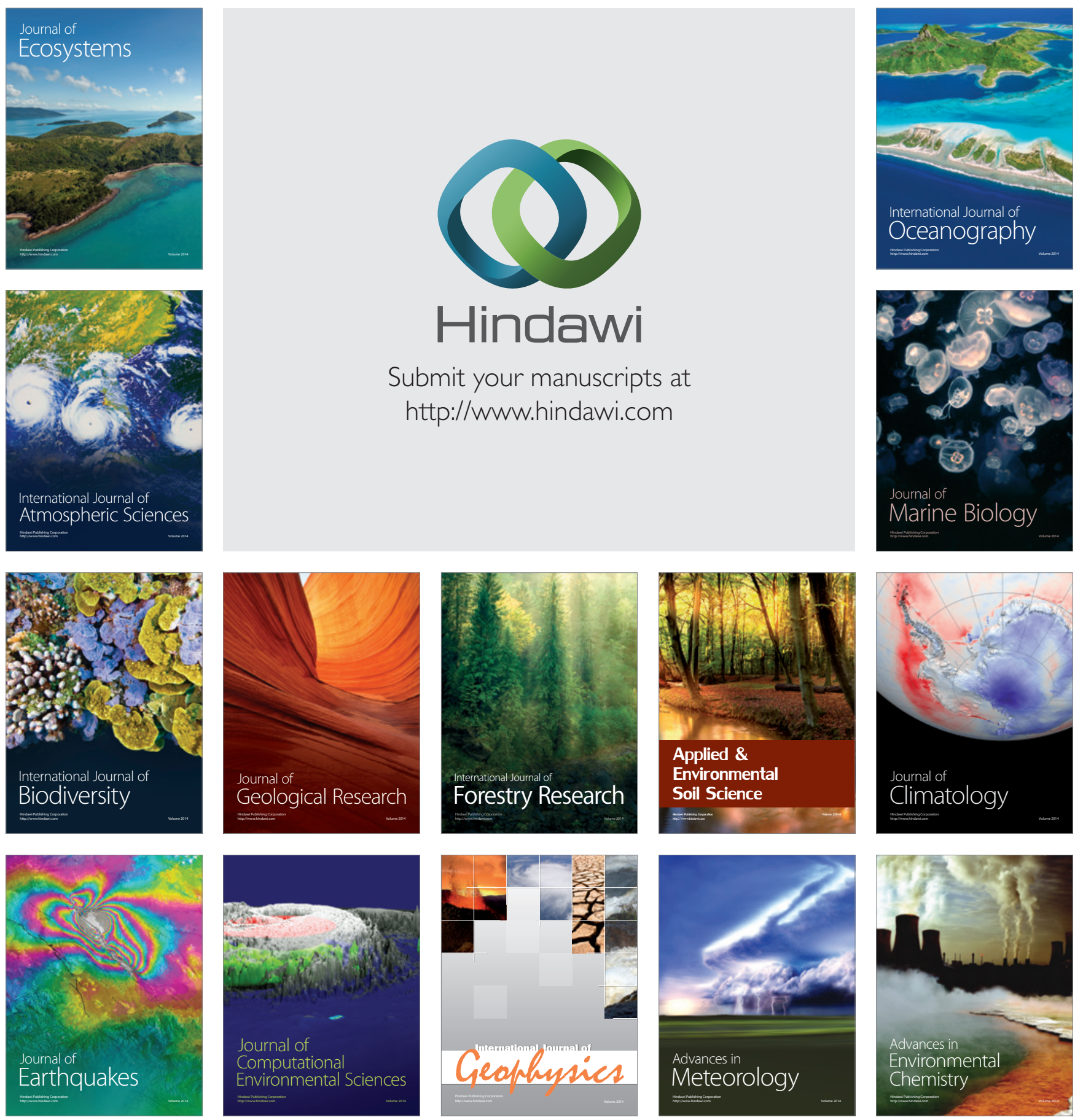